in the fluids or soft parts, and was very difficult of explanation.

Dr. WeBster alluded to the great mortality of phthisis, and to the uselessness of specific remedies in the disease.

Mr. Burgess got up to speak, but the noise made by members leaving the room was so great, that what he said could not be heard.

\section{LIFE-ASSURANCE FEES FOR MEDICAL OPINIONS.}

\section{To the Editor of THE LANCET.}

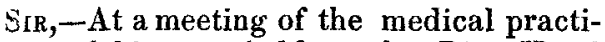
tioners of this town held at the Lion Hotel on the 25th October, 1842, the following resolution was unanimously carried:-"In union with the British Medical Association, we pledge ourselves not to answer the inquiries of insurance offices, unless accompanied by a fee of one guinea." I was also requested to send circulars to the county practitioners, soliciting their assent; and I have much pleasure in informing you that eighty-two have given their assent, and expressed themselves strongly in favour of the resolution. The British Medical Association say, "they think that this fee should be paid by the assurance companies, but it must be a matter of arrangement between themselves and the proposer, whether it, or any part, should be paid by the latter; it should, at all events, accompany the letter which is sent by the company." It is evident, therefore, that the medical attendant, for answering such inquiries, is pledged not to re. ceive the fee direct from his own patient, but it must be either paid or forwarded to him by the office. The profession, then, merely ask the offices to perform an act of courtesy. I am happy to say that the directors of the Salop-and-North-Wales Life Assurance Ofice, on the subject being explained to them last month, readily consented that the fee should be forwarded, with the certificate, by the office to the medical attendant; as it was evident that no class of men enter into similar combinations unless labouring under some practical grievance. The members of the Shropshire Medical Association are urged by principle, feeling, and interest, to adopt the present line of proceeding, and it is their determination, systematically, to discuss the subject with their patients and acquaintances, to point out the unjustifiable advantages taken by the modestly selfstyled "oldest and best offices," and to draw attention to the more equitable and more moderate terms of the new offices, particularly to the invaluable clause of the London, Edinburgh, and Dublin office, making the policies indefeasible and indisputable. There are about one hundred and fifteen, I believe not one hundred and twenty, medical practitioners resident in Shropshire, of whom one hundred and two are now members of this association, and eight more have expressed their approval of the resolution, but decline pledging themselves to act up to it in every case. A similar resolution is now signed by nearly every practitioner in Montgomeryshire, and if the other counties take the subject up with similar spirit and zeal, the assurance companies will in a very short time be compelled to accede to our terms, and no longer treat our wishes and remonstrances with contempt. I am, Sir, your most obedient servant,

R. Cartwright, Hon. Sec. to the

Shropshire Medical Association. Shrewsbury, Jan. 16, 1843.

Doctor Arthur.-To the Editor.-Sir: Some strictures on my conduct having appeared in last week's LANCET relative to an inquest held at Deptford, I beg to send you the Kentish Mercury of Saturday last, in which my letter appears, with an exposure of the disgraceful conduct of the coroner's jury, the treatment adopted by me, and all the particulars connected with the case; and I am confident yon will agree with me that "the thanks which I returned the jury were perfectly suitable to the occasion." I have the bonour to be, Sir, your's, most obediently, Joseph Arthur, M.D., M.R.C.S.L. Deptford, Jan. 13th.

\section{ROYAL COLLEGE OF SURGEONS IN LONDON.}

List of gentlemen admitted members on Friday, January 13, 1843 : H. H. Corbould, F. D. Howell, J. J. Atkinson, R. E. Davies, B. W. Hutchinson, F. O. Barker, H. W. Reynolds, F. J. Burge, T. F. McGauran, R. E. Lutley, R. Rudall, A. Featherstonhaugh.

\section{NEWS AND CORRESPONDENCE.}

Mr. J. C. Atkinson, referring to our note on his case of staphyloma treated with prussic acid vapour, page 520, wishes to observe that in reporting the case he simply " came forward as a medical republican, for the good of the community, and not as the champion of any particular individual, or of empiricism." Of this fact we assure Mr. A. that we have not the slightest doubt. $\mathrm{He}$ adds, "The progress of the case was carefully watched by an assistant, an intelligent gentleman, whose wonder at the rapid improvement in the appearance of the cornea equalled mine. I drew my conclusions that the vapour would prove a powerful agent from its almost visible action, and I question whether many of your correspondents would not have fallen into the same error with myself in the recommendation of a remedy, if the influence exercised by it was only tantamount to, and had not surpassed (as with me), their expectations." "Although," 